$1-1-1992$

\title{
Two Legal Constructs of Motherhood: "Protective" Legislation in Mexico and the United States
}

Antoinette M. Sedillo Lopez

University of New Mexico - School of Law

Follow this and additional works at: https://digitalrepository.unm.edu/law_facultyscholarship

Part of the Law and Gender Commons, and the Law and Race Commons

\section{Recommended Citation}

Antoinette M. Sedillo Lopez, Two Legal Constructs of Motherhood: "Protective" Legislation in Mexico and the United States, 1 Southern California Review of Law and Women Studies 239 (1992).

Available at: https://digitalrepository.unm.edu/law_facultyscholarship/195

This Article is brought to you for free and open access by the UNM School of Law at UNM Digital Repository. It has been accepted for inclusion in Faculty Scholarship by an authorized administrator of UNM Digital Repository. For more information, please contact amywinter@unm.edu, Isloane@salud.unm.edu,sarahrk@unm.edu.

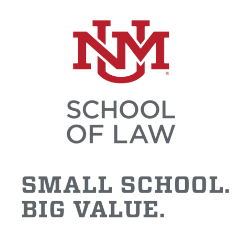

BIG VALUE. 


\title{
TWO LEGAL CONSTRUCTS OF MOTHERHOOD: "PROTECTIVE" LEGISLATION IN MEXICO AND THE UNITED STATES*
}

\author{
ANTOINETTE SEDILlo LOPEZ**
}

\section{INTRODUCTION}

The United Nations Economic and Social Council recently adopted a wide range of recommendations promoting women's rights throughout the world, including a call for increased dissemination of information about women's legal and de facto social status. ${ }^{1}$ In light of the proposed free trade agreements, which will increase interaction between the United States and Mexico, ${ }^{2}$ developing an understanding of women's rights in both countries will become increasingly important. ${ }^{3}$ A comparative analysis of women's legal issues can help us place a feminist agenda in a broader context. ${ }^{4}$

* $\odot 1991$ by Antoinette Sedillo Lopez.

* Associate Professor of Law, University of New Mexico School of Law. Bachelor of University Studies 1979, University of New Mexico; J.D. 1982, University of California, Los Angeles. I would like to thank Anne Waters for research assistance and Robyn Smith for editing. This article is dedicated to Victor and Graciela.

1. 27 U.N. MONTHLY ChroN. no. 3, at 38 (1990).

2. Brenda Dalglish, Rapidly Modernizing Mexico Wants to Create a Free Trade Zone with the United States and Canada, MACleANS, Dec. 3, 1990, at 48.

3. The United States and Mexico have an uneasy relationship. They are neighboring countries with vastly uneven economic resources. They share a violent and bitter history of hostilities toward each other. The peoples of each country also have very different cultures, education, and social development. Moreover, the countries' relationship with each other is challenged by their different legal systems. Mexico has furthered its tradition in the civil law since it was imposed by Spain. The United States has advanced its common law tradition after adopting the English common law. See generally, Alan Riding, Distant Neighbors: A Portrait of the Mexicans 316-39 (1985) (discussing the power relationship between Mexico and the United States); PHILlir Russel.L, MExICO IN TRANSITION 89-94, 121-27 (1977) (discussing the social structure and social services of Mexico).

4. For notable comparative work on women's legal issues, see MARY ANN GLENDON, ABORTION AND DIVORCE IN WESTERN LAW: AMERICAN FAILURES, EUROPEAN Challenges (1987); Margaret E. Leahy, Development Strategies and the Status of Women: A ComparaTive Study of The United States, Mexico, the Soviet Union, AND Cuba (1986); Marsha 
The theme of this symposium, "Reconstructing Motherhood," requires an examination of laws designed to further traditional motherhood roles. Societal constructs of motherhood-women as child bearers and nurturers-have profoundly affected women's involvement in paid employment. Conversely, women's participation in paid employment affects how women experience motherhood. For example, a woman who does not work outside the home has a dramatically different mothering experience than a woman who works outside the home and leaves her children with a day-care provider. The legal system can affect the relationship between motherhood and employment opportunities for women by means of employment laws and policies. Sometimes protective legislation $^{5}$ is enacted in view of women's unique role as potential and actual mothers. Studying forms of protective legislation in different countries can help us to think about ways of reconstructing motherhood. ${ }^{6}$

In both Mexico and the United States, protective legislation has been enacted in ways that control women's experiences as mothers by attempting to further or maintain their traditional role in the family. One justification for the legislation is to protect women's health or the health of an unborn or potential fetus. ${ }^{7}$

This article briefly describes Mexico's unique equal rights amendment and examples of protective employment legislation under Mexican labor law. ${ }^{8}$ For example, Mexico's federal labor laws include regulations designed specifically to protect women's health and to guard against potential harm to fetuses. ${ }^{9}$ The article then outlines the United States' experience with protective legislation. Although the Equal Rights

Freeman, Measuring Equality: A Comparative Perspective on Women's Legal Capacity and Constitutional Rights in Five Commonwealth Countries, 5 BERKELEY WoMEN's L.J. 110 (1990). See also, Heather Dashner, Unionists Propose Women's Issues for NAFTA Negotiations, NoTIMEX MEXICAN NEwS SERVICE, Feb. 10, 1992 (discussing the demands of a trilateral women worker's conference involving women from Mexico, Canada, and the United States).

5. The term "protective legislation" will be used in this article to refer to laws affecting only women-ostensibly to protect their health and the safety or the health of an unborn or even yet-tobe-conceived fetus.

6. Professor Catharine Wells asked me to comment on employment legislation and policy in Mexico and the United States, particularly in light of the recently decided case of International Union, United Automobile Aerospace and Agricultural Implement Workers of America v. Johnson Controls, $111 \mathrm{~S}$. Ct. 1196 (1991). This article is a small piece of a larger body of work analyzing women's issues in Mexico and the United States, planned for publication by the University of New Mexico Press in 1992.

7. See infra text accompanying notes 53-56, 72-73.

8. See infra text accompanying notes $18-69$.

9. See infra text accompanying notes $42-58$. 
Amendment to the United States Constitution failed to pass, anti-discrimination laws have been used to strike down protective legislation under the theory that men and women must be treated equally. ${ }^{10}$ Today, however, we see a resurgence of the notion of protective legislation in the laws enacted and policies pursued in purported attempts to protect fetuses. ${ }^{11}$ But this new protective legislation does not protect fetuses as much as it controls women's reproductive role. ${ }^{12}$ The Johnson Controls ${ }^{13}$ case is a recent example of anti-discrimination law precluding such attempts to control women's reproductive role in society. ${ }^{14}$ Evaluating both countries' experiences with protective legislation reveals a paradox. ${ }^{15}$ Legislation designed to accommodate the unique needs of women as child-bearers and nurturers may limit their employment opportunities. ${ }^{16}$ And, legislation that mandates absolute equality for women may reduce employment opportunities for women in light of their traditional role as child-bearers and nurturers. ${ }^{17}$ Understanding the nature of the paradox can help us to think about alternative approaches to preserving equality while supporting women who choose the role of mother.

\section{MEXICO'S EQUAL RIGHTS AMENDMENT AND PROTECTIVE LEGISLATION}

Although Mexico declared itself independent from Spain in 1810, because of constant internal strife and political upheaval the country did not attain its current democratic government until the late 1850 's. ${ }^{18}$ Until then, according to Margaret Leahy, "the political rights of all Mexicans were limited, and the legal rights of women further circumscribed by Spanish law and, for a short time, the Napoleonic codes." 19 For example, "under both Spanish law and the Napoleonic codes, the concept of community property in marriage prevailed."20 Although both parties had a theoretical right to share in the community property, the husband had the sole right to manage and control that property. Under

10. See infra text accompanying notes 7479.

11. See infra text accompanying notes 88-93.

12. See infra text accompanying note 94 .

13. 111 S. Ct. 1196 (1991).

14. See infra text accompanying notes 95-104.

15. See infra text accompanying notes 109-10.

16. See infra text accompanying notes 59-63.

17. See infra text accompanying notes 101-03.

18. See generally Agustin CuE CANovas, Historia Social y Economica DE MEXico: La REVOLUCION DE INDEPENDENCIA Y MEXICO INDEPENDIENTE HASTA 1854 (1947) (discussing the turbulent history of Mexico from independence to the current democratic government).

19. M. LEAHY, supra note 4 , at 47.

20. Id. at $134-35, \mathrm{n} .1$. 
both legal systems, marriage was a religious as well as a civil state and divorce was forbidden. ${ }^{21}$ The Napoleonic codes forbade "a wife's employment without the express consent of her husband."22 Finally, in any dispute or separation the father had custody and control of his legitimate children. ${ }^{23}$

The 1857 Constitution defined the rights and duties of citizens in the democratic Mexican Republic. ${ }^{24}$ Although "[t]he 1857 Constitution did not explicitly exclude women from voting and holding office ... the election laws restricted the suffrage to males . . .."25

Mexican women's struggle for the franchise was long and bitter. ${ }^{26}$ In 1953, women were finally given the vote, in large part because the ruling party, Partido Revolucionario Institucional (PRI), co-opted women's organizations and ensured that a female voting bloc would not affect the status quo. ${ }^{27}$ In fact, winning the franchise splintered women's groups because they had a difficult time organizing around common issues. ${ }^{28}$

21. Id. at 135, n.1.

22. Id.

23. Id.

24. Id. at 47.

25. Ward M. Morton, Woman Suffrage in Mexico 1 (1962). See also Maria Elena Manzanera del Campo, La Igualidad de Derechos Politicos 143 (1953) (discussing the meaning of the concept of equality as a political right).

26. The twin goals of the 1910 revolution were economic justice and political democracy (La Tierra y La Libertad). These goals were variously interpreted by the assorted groups, including many women's groups, who actively supported the revolution. During the revolution, many women were significant participants. Some were officers and rose to leadership positions, some exercised influence in their role as private secretaries to male leaders. Others participated in combat, especially in the Red Battalions of Workers. Many women expected that the revolution would result in suffrage for women. However, the struggle for women's suffrage may have been overshadowed by the new republic's fear of the power of the Catholic church, in that women were perceived as much more firmly entrenched in the Catholic church. They were seen as a potential voting bloc controlled by the church. So, in addition to laws forbidding parochial instruction and attempting to loosen church control over land, the specific right of women to vote was left unclear in the 1917 Constitution. M. LEAHY, supra note 4, at 47-48.

President Carranzo's decree of September 19, 1910, set the first election date and "authorized ... persons to vote who 'are considered residents of the states qualified to vote for Deputies to the Congress." " W. MORTON, supra note 25, at 5 (quoting Diario Oficial, Ógano DEL Gobierno Provisional de la Républica Mexicana, Sept. 22, 1916). However, only males were qualified to vote for deputies. Between that election law and the formal grant of suffrage in 1953, Mexican women were told they must be prepared for the grant of suffrage. Apparently it took over 40 years for them to prepare. Id. at 14-15.

27. See W. MORTON, supra note 25 , at 61-84.

28. Id. at 88 . 
In 1975 Mexico City hosted the United Nations World Conference of the International Women's Year. ${ }^{29}$ In that same year, Mexico passed a rather interesting equal rights amendment. ${ }^{30}$ Article 4 of the Mexican constitution declares that men and women will be treated equally by law. ${ }^{31}$ However, the very next sentence of article 4 states that laws shall protect the organization and the development of the family. ${ }^{32}$ Because the family is not regarded as an egalitarian institution in Mexico $^{33}$ this

29. NATAlie KaUfman HeVener, INTERNational LAW AND the STATUS OF WOMEN 201 (1983).

30. In the civil law tradition, the primary emphasis is on the text of the code rather than on judicial interpretation. For example, a Mexican district court is not bound by a previous Supreme Court interpretation of a statute unless the Supreme Court has created binding precedent by ruling the same way in five consecutive cases. Mexican lawyers rarely cite cases in their legal briefs. If they cite anything other than the code, they will cite a treatise or other writing by a legal scholar. In addition, the power of the judiciary is limited. Judges do not have the power to declare statutes unconstitutional and thus void. If a litigant has a claim based on a deprivation of a right guaranteed by the constitution, he or she may use the amparo process. Amparo is a legal process roughly similar to a writ of habeas corpus in which the constitutionality of the government action is challenged. However, this proceeding is primarily used in criminal cases and is binding only on the involved litigants. The statute, even if found by the judge to be inconsistent with the constitution, stays on the books until the legislature changes it. Paul Bernstein, El Derecho y El Hecho: Law and Reality in the Mexican Criminal Justice System, 8 ChICANo L. Rev. 40, 45-46 (1985) (citing J. MerRYMAN, The Civil LaW Tradition (1969)). Broad rulings such as Roe v. Wade, 410 U.S. 113 (1973), declaring restrictions on a woman's right to abortion unconstitutional and invalidating all statutes imposing such restrictions are not possible under the Mexican legal system.

31. Constitución Politica de los Estados Unidos Mexicanos title I, art. 4 (Mex.) (reprinted in English in CoNSTrruTION OF MEXICo 1917 (General Secretariat of the Organization of American States 1977)).

32. Id.

33. According to Octavio Paz, a leading Mexican philosopher, the creation of the Mexican race of mixed Spanish and Indian blood caused a deep psychic pain in the Mexican people. On the one hand, the Mexican male feels anger at the Spaniard who raped his mother and, on the other hand, feels anger at his mother for betraying her Indian blood because of the rape. Paz calls this the Malinche syndrome, after Cortez's Indian mistress who served as an interpreter for the Spaniards and bore a son (the first mestizo, or mixed blood) who was fathered by Cortez. Some have claimed that this is the source of "machismo"-the exaggerated notion of male superiority and dominance thought to be a part of Mexican culture. Machismo has also created a mythical image of women in Mexican society. A woman is expected to be a pure, long-suffering wife and mother. It is much worse for her to betray her husband than it is for him to be unfaithful to her. See Octavio PAZ, LABYRINTH OF SOLITUDE: LIFE AND ThOUgHT IN MEXICo 35-40, 66-88 (1961).

In this society of machismo, the father is the undisputed head of the stereotypical Mexican family. He has a domineering relationship with his wife and children. He expects to be pampered at home, but spends much time with friends or a mistress. He neglects his wife and children. The wife, neglected by her husband, accepts his faults and often lives for and through her children. This pattern is repeated for generations in that sons adore and venerate their mother but emulate their father with respect to their wives. Daughters are supposed to repeat the role of their mothers. Alaide Foppa, Para Que Sirve la Familia?, 2 Fem. no. 7, at 41 (1978). See Alan Riding, DisTant Neighbors: A Portrait of the Mexicans (1985). See also Francisco Zarama, Consuelo Zarama, \& Robert Zarama Urdanata, la Familia Hoy, en America Latina (1980) (discussing common traits and structure of the family in Mexico). 
article creates an inherent tension (if not contradiction) between the goals of guaranteeing equality and furthering women's roles within the family. The second sentence of article 4 justifies protective legislation such as mandatory maternity leave, mandatory descansos (breaks for nursing women), laws prohibiting night work and limiting hours, as well as other regulation of working conditions for women-pregnant women, nursing women, and mothers-all in the interests of furthering the family. Such legislation, while accommodating women's roles as mothers, without corollary laws prohibiting discrimination in hiring practices, tends to limit employment opportunities for women.

Recent estimates place the participation of women in the work force in Mexico at approximately $17.6 \%$ of females over the age of eight. ${ }^{34}$ Women tend to be concentrated in domestic service and clerical positions. ${ }^{35}$ Young women between the ages of sixteen and twenty-four are disproportionately represented in assembly line jobs in the border industries (the maquiladoras). ${ }^{36}$

In general, Mexico's constitution and labor laws appear committed to preserving workers' rights. Indeed, the Mexican revolution succeeded, in part, because of the alliance of peasants and workers in the revolutionary cause. ${ }^{37}$ Revolutionary rhetoric about workers' rights was outlined in the 1917 Constitution. ${ }^{38}$ Women's rights and labor reforms, advocated by General Salvador Alvarado, a member of the Constitutional

34. Jorge Leopoldo Rendón, la Participacion de la Mujer en la fuerza de Trabajo: Significado E IMplicaciones: El Caso Específico del Estado de MÉxico 23 (1977). See also César Zazueta, LA MUjer y el. Mercado de Trabajo en Mexico 65-70 (1981). Obviously, a greater percentage of men than women are employed in the work force. However, when the economy grows, the number of women participating in gainful employment increases. Women in urban areas are more likely to work outside the home than women in rural areas. Women in the age group between 15 and 24 are more likely to participate in the work force. Divorced, separated, or widowed women are more likely to work than women who have never married, married women, or women living with someone in an union libre. Generally, better educated women tend to work outside the home more often than women with minimal education. If other members of the family work, such as husbands, sons, daughters, cousins, or uncles, the mother of the family is less likely to work outside the home. In rural homes, with many young children in the home, the likelihood of a woman working outside the home is high. Thus, the biggest factor affecting whether women work outside the home is economic need. $I d$.

35. Id. at 55.

36. Susanna Peters, Labor Law for the Maquiladoras: Choosing Between Workers' Rights and Foreign Investment, 11 COMP. LAB. L.J. 226, 243 n. 91 (1990).

37. John Womack, JR., Zapata and the Mexican Revolution (1968); Mary K. Vaughan, Women, Class and Education in Mexico 1880-1928, in WOMEN IN LATIN AMERICA: AN ANTHOLOGY FROM LATIN AMERICAN PERSPECTIVEs $69-70$ (1979).

38. Vaughan, supra note 37 , at $70-71$. 
Army, were incorporated into the Mexican Constitution of $1917 . .^{39}$ General Alvarado believed in individual freedoms and competition, and he championed the liberation of women from religious discrimination, male domination, and economic servitude. ${ }^{40}$ Specifically, General Alvarado advocated women's rights to divorce, political participation, education, increased vocational training, and admission to the professions. ${ }^{41}$ His labor reforms, which were also incorporated into the Mexican Constitution of 1917, encouraged traditional family life by giving workers the right to organize and bargain, by setting minimum wages and maximum hours, by setting limits on and establishing protection of child labor, and by establishing maternity leaves and rest periods for nursing mothers. ${ }^{42}$ Most of these reforms are presently reflected in article 123 of Mexico's current constitution and in the Federal Labor Act of $1970 .{ }^{43}$

The Mexican constitution requires equal wages for equal work regardless of sex or nationality. ${ }^{44}$ Both the federal Mexican labor law and the Mexican constitution ${ }^{45}$ require state and federal governments to provide pregnant women with a six-week paid maternity leave prior to

39. Id.

40. Id.

41. Id.

42. Id.

43. See Constitución Politica de los Estados Unidos Mexicanos title VI, art. 123 (Mex.); Ley Federal de Trabajo [L.F.T.] (Spanish and English text of current Mexican federal labor law reprinted in MEXICAN LABOR LAW (Commerce Clearing House, Inc. 1978)).

44. Constitución Polmica de los Estados Unidos Mexicanos title VI, art. 123, para. A-VII (Mex.).

45. See U.S. Dep't of STATE, 102D CONG., Ist Sess., Country Reports on Human Rights PrACTICES For 1990 696-700 (1991). This report states:

The Constitution also provides for a minimum wage for workers, with variations for geographic zones and professional specializations. ... The U.S. Labor Department study noted that the Government, in controlling the minimum wage (which serves as a benchmark) has not always been able to help workers keep up with inflation and the devaluations of the peso. It finds itself, according to the study, in the difficult position of trying to balance its desire to improve the social lot of workers with its desire to retain employers who might otherwise go elsewhere.

The maximum legal work week is 48 hours. In recent years, the average workweek has declined considerably, to a level of approximately 42 to 43 hours... . The Constitution provides for required rest periods, stipulating that workers who do, in fact, put in more than 3 hours of overtime per day or work overtime more than 3 consecutive days must be paid triple his regular wage rate. Anecdotal evidence suggests that workers frequently exceed these work hours.

With respect to occupational health and safety, legislation is relatively advanced and provides substantial protection. Health and safety standards are better observed in large firms. There appears to be a higher incidence of industrial accidents in smaller firms and on construction sites. This does not reflect inadequate legislation, but rather too few inspection personnel to monitor adequately health and safety regulations. Mexican labor law requires the formation of mixed commissions of government, labor, and workers to oversee security and hygiene; it also sets conditions for compensation due to work-related illness or injury.

Id. at 699-700. 
birth and a six-week paid maternity leave after birth. ${ }^{46}$ Further, under the federal labor law, non-government employers are also required to provide a six-week pre-birth paid maternity leave and a six-week afterbirth paid maternity leave. ${ }^{47}$ After the child's birth, the law allows for two additional breaks a day in order to allow a nursing mother to continue nursing when she is at work. ${ }^{48}$ The employer must provide an adequate and sanitary place for this lactation period. ${ }^{49}$

During maternity leave, women are to receive full salary for the mandatory period; if they take an extension of the mandatory period, they are also entitled to fifty percent of their salary for up to sixty days. ${ }^{50}$ They are entitled to return to their jobs if they return within a year after their child's birth. ${ }^{51}$ Their maternity leave periods are included in computations of seniority. ${ }^{52}$ Employers are directed to adopt measures to "ensure the greatest possible guarantee for the health and safety of workers" and, in the case of pregnant workers, for their unborn children. ${ }^{53}$ Pregnant women are prohibited from working in jobs which would endanger the health of the woman or of her fetus and from working after ten in the evening. ${ }^{54}$ In addition, a woman may not work over-time when her health or the health of her fetus is in danger. ${ }^{55}$ The labor law also requires that sufficient chairs or seats be provided for pregnant

46. L.F.T. title fifth, art. 170, para. II; ConstrTucion Politica DE LOS EsTADos UNidos Mexicanos title VIr, art. 123, para. V (Mex.).

47. Constitución Politica de los Estados Unidos Mexicanos title VII, art. 123, para. $\mathrm{V}$ (Mex.) ("They [women] shall necessarily be entitled to six weeks leave prior to the approximate date of child birth and to six weeks leave thereafter.").

48. L.F.T. title fifth, art. 170, para. IV; ConsTitución Politica DE los EsTados UNidos Mexicanos title VII, art. 123, para. V (Mex.).

49. L.F.T. title fifth, art. 170, para. IV.

50. Id. at title fifth, art. 170, paras. III, V.

51. Id. at title fifth, art. 170, para. VI.

52. Id. at title fifth, art. 170, para. VII.

53. Constitución Politica de los Estados Unidos Mexicanos title VI, art. 123, para. A-XV (Mex.).

54. L.F.T. title fifth, art. 166.

55. Id. Given the weak economy in Mexico, most people cannot support their family based on the $\mathbf{4 8}$ hour work week. Overtime is an economic necessity. Instead of receiving higher overtime pay from employers reluctant to pay it, Mexicans often take second jobs to survive. 1990 HUMAN RIGHTS REPORT, supra note 45, at 699. 
working women to use. ${ }^{56}$ Additionally, child care services are to be provided by the Mexican Institute of Social Security. ${ }^{57}$ Mexicans are quite proud of these special protections for women. ${ }^{58}$

When employers comply with their legal obligations, ${ }^{59}$ pregnant women may use these protections to tend to their traditional family role as child-bearer and nurturer. However, some problems exist. First, not all women want or need these provisions. ${ }^{60}$ Many working women do not have children. ${ }^{61}$ Even among women who have children, not all of them would choose to use the protections afforded them. ${ }^{62}$ Second, Mexico does not have legislation prohibiting employment discrimination in hiring based on sex, pregnancy, or potential for pregnancy. Accordingly, some employers concerned with the potentially high cost of employing women who might need these mandatory benefits discriminate against women. In addition, some companies require women to state that they are infertile on job applications. ${ }^{63}$ If a woman becomes pregnant after stating she is infertile, she may be fired for lying on the job application. ${ }^{64}$ Thus, protective legislation has a negative effect on women's employment opportunities.

In Mexico, protective legislation furthers a concept of the family in which the husband is the head of the household and their wives are their dependents and the bearers and nurturers of their children. ${ }^{65}$ Protective legislation is viewed by many Mexicans as progress in improving most women's lives. ${ }^{66}$ The fact that protective legislation may reduce employment opportunities for women is viewed by some as positive support for

56. L.F.T. title fifth, art. 172.

57. Id. at title fifth, art. 171. Unfortunately, child care is not always adequate. Interview with Licenciada Patricia Begne, Professor, Universidad de Guanajuato, author of MANUAL DE LoS DERECHOS DE LA MUJER (1987) (Nov. 5, 1991).

58. Interview with Licenciado Juan Renee Segura, Mexican labor lawyer and Professor, Universidad de Guanajuato, Facultad de Derecho (Fall 1990) ("Mexico still believes that the most important unit in its society is the family. The United States believes that the most important unit in society is the almighty dollar.").

59. Most employers fail to comply with these provisions. Id.

60. Interview with Lic. Patricia Begne (June, 1990).

61. J. RENDON, supra note 35 , at 77.

62. Pregnancy leaves may detrimentally affect the careers of some women. Interview with Lic. Begne, supra note 57.

63. See, e.g., Marlise Simons, Brazil Women Find Fertility May Cost Jobs, N.Y. Times, Dec. 7, 1988, at A11, col. 1 (describing the identical problem in Brazil).

64. Id.

65. See supra note 33.

66. JosE Antonio Alonso, Sexo, Trabajo y Marginalidad URbana 96-97 (1981) (study of women's participation in the work force in Nezahualcoyotl. Only $24 \%$ of the women worked outside the home for a salary, and $46 \%$ worked in their own home. $38 \%$ of the women who worked 
the traditional family. ${ }^{67}$ Further, some feminists in Mexico advocate for enforcement of protective legislation such as day care and pregnancy leaves. ${ }^{68}$ Others are aware of its negative impact on women's employment opportunities. ${ }^{69}$

\section{PROTECTIVE LEGISLATION IN THE UNITED STATES}

In the early 1900's feminists in the United States also supported protective legislation as a means to improve women's lives. ${ }^{70}$ For example, in the United States Supreme Court case of Muller v. Oregon, ${ }^{71}$ Louis Brandeis, representing several women's organizations, argued that Oregon laws limiting a factory woman's labor to ten hours a day should be upheld because, as potential mothers, women needed special legislation to protect them from jobs or occupational situations that could negatively affect their health. ${ }^{72}$ However, the court in Muller did not focus on protecting women's health or improving women's lives. Rather, the Court focused on the health of potential offspring. In upholding the ten hour-a-day limit for female factory workers, the court stated: "[H]ealthy mothers are essential to vigorous offspring, the physical well-being of women becomes an object of public interest and care in order to preserve the strength and vigor of the race."73 Thus, in 1906, protective legislation protected women's health as a corollary to protecting (and controlling) women's reproductive role in society.

When the Supreme Court in Adkins v. Children's Hospital ${ }^{4}$ later declared a law setting minimum wage for women unconstitutional, the National Women's Party found this to be a victory for women's rights; however, many women's groups and labor organizations denounced it as

outside the home worked as domestics, $16 \%$ had small businesses, $9 \%$ were manual laborers, $1 \%$ were professionals, and $10 \%$ were factory workers).

67. Interview with Lic. Segura, supra note 58.

68. Patrick Oster, The Mexicans: A Personal Portrait of a People 270 (1989) (portrait of "la femenista": "[feminists] discuss whether Mexican women will ever get adequate day care or paid maternity leaves.").

69. Interview with Lic. Begne, supra note 57.

70. See Eleanor FlexNer, Century of Struggle: The Woman's Rights Movement IN THE UNITED STATES chaps. 9, 14, 18 (rev. ed. 1975); William L. O'NeIll, EVERYONE WAS BRAVE: The RISE AND FALl OF Feminism IN AMERICA 152-53 (1969).

71. 208 U.S. 412 (1908) (upholding Oregon's minimum hour legislation as applied only to women).

72. Mary Ann Mason, Motherhood v. Equal Treatment, 29 J. FaM. L. 1, 3-4 (1990-91). See also CARL N. Degler, At OdDS: WoMEn AND THE FAMILY IN AMERICA FROM THE REVOluTION TO THE PRESENT (1980) (discussing women's early support for protective legislation).

73. 208 U.S. at 421.

74. 261 U.S. 525 (1923), overruled by West Coast Hotel Co. v. Parrish, 300 U.S. 379 (1937). 
a retreat from Muller v. Oregon. ${ }^{75}$ Interestingly, the Court in Adkins did not retreat dramatically from the idea that protecting women's health was a constitutionally permissible objective. ${ }^{76}$ Rather, the Court found a relationship between numbers of hours worked and women's health, ${ }^{77}$ but little relationship between minimum wages for women and women's health. ${ }^{78}$ Thus, the doctrinal basis for treating men and women equally was not developed in Adkins, despite the National Women's Party support for the opinion. ${ }^{79}$

More recently, after a long struggle, the proposed Equal Rights Amendment to the U.S. Constitution failed to pass. ${ }^{80}$ However, antidiscrimination legislation such as the Civil Rights Act of $1964^{81}$ and several executive orders, ${ }^{82}$ together with the subsequent judicial interpretation of these laws, have served to dismantle protective legislation. The judicial effort has invalidated mandatory maternity leave, ${ }^{83}$ laws restricting women's work hours and how much weight they could lift, ${ }^{84}$ and other protections ${ }^{85}$ that had been enacted during the first forty years of the twentieth century.

75. See C. DEGLER, supra note 72 , at 403.

76. 261 U.S. at 554.

77. Id.

78. Id. at 555 .

79. C. DEGLER, supra note 72 , at 403 . This conflict between protective legislation and equal treatment bedeviled feminists in this country for many years. See, e.g., SUSAN D. BECKER, THE Origins of the EQUAL Rights AMENDMENT: AMERICAN Feminism Between the Wars (1981). Further, this conflict is still an issue in the feminist debate between equal treatment and special treatment. See, eg., Alison M. Jaggar, Sexual Difference and Sexual Equality, in THEoRETICAL Perspectives on Sexual Differences (Deborah L. Rhode ed. 1990); Christine A. Littleton, Reconstructing Sexual Equality, 75 CALIF. L. REv. 1279 (1987).

80. Mary Frances BerRy, Why ERA FaIled: Politics, Women's Rights, and the amending Process of the Constitution (1986); William Henry Chafe, The American Woman: Her Changing Social, Economic, ANd Political Roles, 1920-1970, 112-32 (1972). See generally Janet K. Boles, The Politics of the Equal Rights Amendment: Conflict AND THE Decision Process (1979) (discussing the various pressures that came to bear in the attempted passage of the equal rights amendment).

81. 42 U.S.C. $\$ \S 2000 \mathrm{e}$ to $2000 \mathrm{e}-17$ (1988).

82. Exec. Order No. 11246, 3 C.F.R. 339 (1964-1965), reprinted in 3 U.S.C. $\$ 2000 \mathrm{e}$ app. at 398-401; Exec. Order No. 11375, 3 C.F.R. 684 (1966-1970); Exec. Order No. 11478, 3 C.F.R. 803 (1966-1970), reprinted in 3 U.S.C. $\$ 2000$ e app. at 402.

83. E.g., Schattman v. Texas Employment Comm'n, 459 F.2d 32 (5th Cir. 1972) (upholding mandatory maternity leave after seven months of pregnancy), cert. denied, 409 U.S. 1107 (1973).

84. E.g., Rosenfeld v. Southern Pacific Co., 444 F.2d. 1219 (9th Cir. 1971) (laws regulating women's work hours and weights they could lift violate Title VII of the Civil Rights Act of 1964).

85. See, e.g., Krause v. Sacramento, 479 F.2d. 988 (9th Cir. 1973) (invalidating law prohibiting women from working as bartenders). See also WOMEN's BuREAU, U.S. DEP'T OF LABOR, STATUS of State Hour Laws for Women Since Passage of Title VII of the Civil Rights Act of 1964 (July 1, 1972) (discussing changes in state laws restricting hours women could work since passage of civil rights legislation). 
Recently, more women have been entering the work force. ${ }^{86}$ Unfortunately, despite the passage of the Equal Pay Act, women have consistently earned less than men. ${ }^{87}$ Interestingly, there appears to be another "protective" movement gathering strength in the United States. After years of chipping away at abortion rights, massive attempts to finally reverse Roe v. Wade ${ }^{88}$ have been launched. ${ }^{89}$ The Supreme Court has permitted the government to deny federal funds to family planning clinics that counsel about abortion as a method of family planning. ${ }^{90}$ Commentators urge states to use resources to punish or jail pregnant addicts rather than to treat them. ${ }^{91}$ Court orders have been issued forcing women to have cesareans against their will in order to protect the fetus. ${ }^{92}$ Employers have enacted fetal protection policies in the workplace to protect fertile women from working in jobs thought to be dangerous to the potential fetus. ${ }^{93}$

These laws and policies may appear to be an attempt to protect fetuses but, in fact, they control women's reproductive roles and only indirectly affect fetuses. If the government really wanted to ensure healthy fetuses, it would channel money to adequate prenatal care, daycare, birth control, treatment and education programs, and safe workplaces for all workers. This new wave of legislation and policies controls women's reproductive role in society by limiting women's ability to choose when to give birth and how to manage their pregnancies. This

86. In $1986,55.3 \%$ of women over age 16 participated in the work force, up from $37.7 \%$ participating in 1960. Bureau of THE Census, U.S. DeP'T OF Commerce, Statistical ABSTRACT OF THE UNITED STATES 365, no. 607 (1988).

87. See generally WOMEN, WORK AND WAGES: Equal PAy for Jobs of Equal Value (Donald J. Treiman \& Heidi I. Hartmann eds. 1981) (report on the validity of compensation systems and methods for determining the relative worth of jobs, including the question of whether and to what extent existing pay differences between jobs are the result of discrimination).

88. 410 U.S. 113 (1973) (a state may not prohibit a woman's decision to terminate her pregnancy prior to viability of the fetus).

89. See Robert D. Goldstein, MOTHer Love AND Abortion: A Legal INTERPRETATION 1-37 (1988) (a comprehensive description of the positions of "regulators" and "deregulators" in the current abortion debate).

90. Rust v. Sullivan, 111 S. Ct. 1759 (1991).

91. See, e.g., Kathryn Schierl, A Proposal to Illinois Legislators: Revise the Illinois Criminal Code to Include Criminal Sanctions Against Prenatal Substance Abusers, 23 J. MARSHALL L. REv. 393, 402-07 (1990).

92. See, e.g., Nancy K. Rhoden, The Judge in the Delivery Room: The Emergence of CourtOrdered Cesareans, 74 CaLIF. L. REv. 1951 (1986).

93. See, e.g., Wendy W. Williams, Firing the Woman to Protect the Fetus: The Reconciliation of Fetal Protection with Employment Opportunity Goals Under Title VII, 69 GEO. L.J. 641 (1981). 
protective "movement" elevates the perceived interests of fetuses over the interests of women. 94

However, antidiscrimination laws may provide a means to curb attempts to control women's reproductive role. For example, on March 20, 1991, in International Union v. Johnson Controls, ${ }^{95}$ the Supreme Court unanimously struck down a "fetal protection policy" instituted by Johnson Controls, Inc. which excluded women who could not medically document their infertility from working in a battery manufacturing plant.

Justice Blackmun, writing the majority opinion, framed the issue as whether an employer may exclude a fertile female employee from certain jobs because of the employer's concern for the health of a fetus the woman might conceive. Despite evidence about the effect of lead exposure on the male reproductive system, Johnson Controls chose only to apply exclusionary policies to fertile females. ${ }^{96}$ Thus, all women were treated as potentially pregnant, and no men were treated as at risk. The Court determined that such an exclusion violates the Pregnancy Discrimination Act and constitutes sex discrimination under Title VII, ${ }^{97}$ and therefore found that the Johnson Controls fetal protection policy facially discriminated against women on the basis of sex and potential for childbearing. ${ }^{98}$

After finding that the policy constituted discrimination on the basis of sex under Title VII, ${ }^{99}$ the Court went on to find that Johnson Controls could not show infertility as a bona fide occupational qualification because the protection of unborn potential fetuses did not relate to the "essence" of the business of manufacturing lead batteries. ${ }^{100}$ The Court cited Muller $^{101}$ as a case where concern for a woman's potential offspring historically served as an excuse for denying women equal employment opportunities. The Court in Johnson Controls concluded: "It is no more

94. "Fetus-mania" is a term coined in seminar classes I have taught entitled "Reproductive Technology and the Law." Fetus-mania is defined as elevating the interests of fetuses over pregnant (or even non-pregnant) women. I am grateful to all the students who have taken the class for the many insights they have shared with me.

95. $111 \mathrm{~S}$. Ct. 1196 (1991). This case and its relation to reproductive rights are also discussed in Laura C. Fry, Is It Enough that Johnson Controls?, 1 S. CAL. REv. L. \& WoMEN's STUD. 255 (1992).
96. $111 \mathrm{~S}$. Ct. at $1199-1200$.
97. 42 U.S.C. $\$ 2000 \mathrm{e}(\mathrm{k})(1988)$.
98. Johnson Controls, 111 S. Ct. 1196.
99. Id. at 1203.
100. Id. at 1205-06.
101. Id. at 1210, citing Muller v. Oregon, 208 U.S. 412 (1908). 
appropriate for the courts than it is for individual employers to decide whether a woman's reproductive role is more important to herself and her family than her economic role. Congress has left this choice to the woman as hers to make."102 This is an example of the Court finding that antidiscrimination law prohibits an employer from controlling a woman's individual choices about her reproductive role. The District Court ${ }^{103}$ and the Seventh Circuit ${ }^{104}$ had both viewed all fertile women as pregnancies waiting to happen. All fertile women were potentially pregnant women. The lower courts then elevated potential fetuses' interests above the interests of the potentially pregnant women workers, thus treating women as vessels without autonomy to make choices relating to their reproductive roles. The Supreme Court's reversal is a message that women as individuals should be afforded choices by employers about their reproductive roles to the same extent as men. In short, antidiscrimination law in this case precluded an attempt to control women's reproductive role.

Despite the invalidation of protective legislation and the corresponding enhancement of employment opportunities, women are still concentrated in "pink collar" and service jobs and earn substantially less than their male counterparts. ${ }^{105}$ Additionally, many middle class women who enter the work force find it difficult to balance their family roles with their employment responsibilities (a problem that many minority, working class, and poor women have experienced for generations). ${ }^{106}$ Much has been written about the dilemma women face because of the double burden of family responsibilities and employment responsibilities. ${ }^{107}$ Because men do not assume responsibility for children to the extent women do, ${ }^{108}$ the burden of balancing family and work has not

102. $111 \mathrm{~S}$. Ct. at 1210 .

103. 680 F. Supp. 309 (1988).

104. 886 F.2d 871 (1989).

105. E.g., The American Woman 1988-89, A Status Report 387 (Sarah E. Rix ed. 1988).

106. See, e.g., Project, Law Firms and Lawyers with Children: An Empirical Analysis of Family/ Work Conflict, 34 Stan. L. Rev. 1263, 1274 (1982); Mary Joe Frug, Securing Job Equality for Women: Labor Market Hostility to Working Mothers, 59 B.U.L. REv. 55 (1979).

107. See, e.g., Heidi Hartmann, The Family as the Locus of Gender, Class and Political Struggle: The Example of Housework, 6 SIGNS 366 (1981); Barbara Wolfe and Robert Haveman, Time Allocation, Market Work and Changes in Female Health, 73 AMERICAN ECONOMIC REview 12, 134-39 (1983); Lee Teitelbaum, Antoinette Sedillo Lopez, Jeffrey Jenkins, Gender, Legal Education and Careers, 41 J. LEG. Educ. (1991) (manuscript on file with author).

108. Martha S. Hill, Patterns of Time Use, in Time, Goods, AND WELL-BEING 133 (F. Thomas Juster \& Frank P. Stafford eds. 1985); Elizabeth Maret \& Barbara Finlay, The Distribution of Household Labor Among Women in Dual-Earner Families, 46 J. MARRIAGE \& FAM. 357, 360 (1984). 
proven to be as problematic for men. Thus, equal treatment in employment opportunities does not address the real problems women face because of their traditional family role.

\section{CONCLUSION}

The traditional structure of the family tends to define motherhood. Mexico, because of its cultural preference for la familia, has chosen to further its version of the traditional structure of the family with protective legislation because women's biological differences in childbearing and nurturing justify protective legislation. This has enabled some employed women in Mexico to attend to their role in the traditional family structure more easily after having children. However, protective legislation has also limited many Mexican women's employment opportunities.

In the United States, antidiscrimination laws have served to strike down legislative and employer attempts to control women's reproductive role in the family. Permitting women to make those choices has theoretically enhanced their employment opportunities. Thus, women are treated as autonomous, independent moral agents with the same choices afforded to men in balancing employment and family. Unfortunately, because of the traditional family structure, balancing employment with family responsibilities is more difficult for many women than it has been for men.

In comparing the two countries' approaches to women and employment, the paradox between protective legislation and equality becomes apparent. Protective legislation designed to accommodate women's pregnancy and childbearing, in the absence of antidiscrimination law, tends to limit women's employment opportunities. However, women in Mexico who choose to have children can more easily attend to their families. In contrast, in the United States, women's employment opportunities are not limited by protective legislation. However, because of women's traditional role in the family structure, pursuing employment opportunities and having families poses arduous difficulties which may de facto limit women's opportunities.

Perhaps what is needed is a combination of approaches which accommodate women's unique biological needs while ensuring that such accommodations do not attempt to control women's reproductive role. In reconstructing motherhood we should consider advocating for 
optional maternity leaves, paid for by the government, ${ }^{109}$ and optional flexible work schedules. ${ }^{10}$ We should support affordable quality day care. We should continue to support equal pay and antidiscrimination laws. These types of reforms would support women who choose the role of mother while serving the principle of treating men and women equally.

109. Of course, universal child care and health care would also solve many problems for working women as well as children in this country.

110. And we must think about creative ways of providing employers with incentives to provide flexible work schedules. 